\title{
The Role of Courts and Constitutions in the New Politics of Welfare in Latin America
}

\author{
Daniel M. Brinks and William Forbath
}

Like many middle-income countries (MICs), Latin American welfare states are squeezed between demands for basic social goods and neoliberal policy prescriptions backed by the pressures of a globalized economy. They are pressed to limit taxes, services, and the public sector in order to grow their economies by neoliberal lights; but they have sufficient resources to make the prospect of providing basic goods for their vulnerable populations more than a pipe dream. In MICs across the world, but perhaps especially in Latin America, social movements and reformers seeking ways to resist pressures to limit the welfare state have turned to economic and social rights (ESR) as a tool of mobilization. In alliance with courts, these advocates for ESR have sometimes been successful in tempering the harsher impulses of neoliberalism, and even in expanding and broadening the reach of public provision of goods like health care, housing, or water.

It is our suggestion that the politics of the welfare state in MICs are often shaped by the nature of this alliance between courts and ESR advocates. When courts take a more active role, they can become the central axis of debate, conflict, and cooperation among legislators, members of the executive, and social movements; when courts take a back seat, the debate remains more traditional, and social movements and their allies are generally weakened. Moreover, the forms that judicial "activism" may take also make a critical difference. Courts' interventions can be more policy oriented, or less so; they can address individual grievances or systemic problems, and this too shapes how their intervention will affect politics. In many countries, courts have come to supply crucial deficits in the state, prodding inert central ministries into action; spotlighting large and small gaps in public policy; and lending political leverage and moral authority to ESR movements and advocates. In this way courts can compensate, in some measure, for deficits in responsiveness and accountability toward the mass of poor and vulnerable citizens on the part of bureaucrats, elected officials, and party elites, even under conditions of democratization.

At the same time, however, it is clear that courts are not a panacea, either for activist groups seeking to preserve or broaden social programs, for central governments seeking to monitor compliance with centrally developed policies, or for MICs 
seeking to negotiate the perilous terrain of development with equity. Often in tension with technocrats who do not wish to cede authority to the courts and with economists fearful of immodest demands on the national fisc, ESR movements and courts find they must engage with many other actors in many-sided strategies and dialogues to succeed.

Recently, though, economic and social rights-based reform has gotten a surprising boost from the demise of the neoliberal Washington Consensus among state elites. State economists, planners, and policy makers, the technocracy, have begun turning away from free market orthodoxy over the past decade. The region has seen a shift toward models of the "new developmental state," or what some have called "Latin American neostructuralism." This new account of development and economic growth has many facets, some of them hotly debated, as we will note, but one precept has gained real traction: ending extreme poverty and assuring a decent minimum of goods like food and water, health, housing, and education are no longer the hoped-for results of good economic policy, but instead are essential ingredients of it. What the ESR-minded lawyers call the progressive realization of social and economic rights, the new developmentalist-minded economists call "investment" in "human capital" through health care, education, broad access to social assistance, and other improvements in the material welfare of the population.

To be sure, efficiency-minded state technocrats can be expected to be leery of the seeming absolutism of rights talk. But whereas free market fundamentalism insists on holding social policy austerely apart from economic policy, the new developmentalism enjoins state economists to wed the two. And while some of the region's important Constitutional Courts remain wedded to a formalist style of jurisprudence, others have adopted a more pragmatic, contextualized, policy-minded style of legal reasoning. Thus, as we will see, the ESR-bearing provisions of the new Latin American constitutions seem to have new salience in the corridors of state power, and a new space has opened for commerce between constitutional courts and ESR advocates, on the one hand, and technocrats in the administrative state, on the other. When and where this happens, the ESR movements seem likely to be more successful in mobilizing all the different aspects of their repertoire toward advancing what several new constitutions call the progressive realization of ESR.

What has emerged in Latin America and other MIC regions, then, as a consequence of the peculiar position in which MICs find themselves in the global economy today, is a set of social and institutional practices around ESR. Their goal is to refound a welfare state in the context of a global economy and the dominance and discontents of neoliberal economic policy. Over the last twentyfive years, in MICs around the world, social democratic-minded attorneys and

1 Fernando Ignacio Leiva, Latin American Neostructuralism: The Contradictions of Post-neoliberal Development (University of Minnesota Press, 2008). See also David Trubek, "Developmental States and the Legal Order: Towards a New Political Economy of Development and Law," unpublished paper, University of Wisconsin (2010), on file with the authors. 
health care and other professionals along with social movements and nongovernmental organizations (NGOs) have mobilized a discourse of ESR from constitutions and international human rights documents toward this end. Confronting the lack of both adequate social provision and the political will or administrative state capacity to deliver it to broad swathes of the citizenry, these actors have sought to leverage the new prestige and authority of liberal democratic constitutions and constitutional courts. Through the courts, they have made new ESR-based claims on the state, polity, and expanding economic pie of MICs. The peculiar subject matter of these rights, however, and the difficulties inherent in realizing them, have forced sophisticated advocates into a new blend of legal, social movement, and more traditional alliance-building and policy-making strategies. Sometimes they have pushed the courts - and sometimes, conversely, sophisticated courts have pushed them - into a new style of adjudication that is more cooperative and open ended than traditional judicial styles.

In this chapter we first describe the constitutional developments that laid the foundation for ESR-based politics. Then in very brief and stylized fashion we outline the history of the welfare state in Latin America, as an example of the policy context facing ESR-oriented groups in MICs around the world. Next we detail the groups' strategies and the courts' response to these demands. We end with a brief account of what some groups have achieved, in some countries. The goal is neither to offer a comprehensive account, nor a representative sample of experiences. Rather, we outline general patterns and possibilities, as a way to open a window on the pressures MICs face to balance development and social justice, and the ways organized civil society and courts have interacted, using the language and tools of ESR to promote these ends.

THE BURGEONING OF ECONOMIC AND SOCIAL RIGHTS IN 1980S-1990S LATIN AMERICAN CONSTITUTIONS - SOCIAL DEMOCRATIC PROMISSORY NOTES IN NEOLIBERAL POLITICAL ECONOMIES

Most countries in Latin America, as most MICs globally, have incorporated a broad range of ESR into new constitutions, or through significant amendments to old constitutions. Even countries that have long had such rights at the formal level have strengthened the institutional framework for claiming these rights, by reforming their constitutional courts, crafting new forms of action, and easing access to justice. The global history of the constitutionalization of ESR begins in Latin America, with the Mexican constitution of 1917. To cite only one example, this constitution promises remarkable labor rights under Article 123, including humane and healthy working conditions, limits on child labor, and a minimum wage. ${ }^{2}$ During the first

2 Constitución Política de los Estados Unidos Mexicanos [Political Constitution of the United Mexican States], art. 123 . 
half of the twentieth century, the social rights in this constitution found an echo in other constitutions. President Getulio Vargas's short-lived 1934 Constitution for Brazil was the first constitutional guarantee of ESR in that country. President Juan Perón wrote a social constitution for Argentina in 1949, which was derogated after the 1955 coup that sent him into exile. But Mexico's constitutional promises were poorly realized, if at all, and an alliance between the military and elite economic interests soon scotched the early expressions of populist ESR-oriented constitutionalism in Argentina and Brazil. Though many of the provisions remained in constitutional texts, social constitutionalism, as a source of democratic energy, protest, and claim making, was fully derailed when the region plunged into dictatorship and repression in the 1970 and 1980 .

ESR and social constitutionalism truly became the dominant pattern in Latin America as the region began to return to democracy in the 1980s. If the first generation of economic and social rights-bearing provisions in Latin American constitutions were the fruits of authoritarian populism, aimed at heading off radical leftist demands, the new social constitutionalism arose in a different conjuncture. This time the revolutionary left frequently had a seat at the drafting table - sometimes having forsaken the armed struggle in direct exchange for a role in the constitution-making process - and this time their more conservative negotiating partners were representatives of political and economic elites with genuine commitments to a liberal democratic constitutional order. The gulf between them lay in the elites' sometimes equally deep commitments to safeguarding a neoliberal political economy. The upshot was often a Janus-faced constitutional text that looked toward institutionalizing the Washington Consensus of strong property rights, independent central banking, and the like, even as the text also brimmed with social democratic aspirations and promises.

A signature example was the drafting of Colombia's 1991 constitution. This constitution is an amalgam of neoliberal and social democratic impulses. César Gaviria, an economist who had been instrumental in bringing the neoliberal project to Colombia, was president at the time of Colombia's constitutional convention. ${ }^{3}$ Pushed into the convention by popular demands, Gaviria aimed to crystallize that project in the new constitution. The president's constitutional draft protected property rights, removed barriers to foreign investment, allowed for private ownership of former state enterprises, and created an autonomous central bank. But the M19, a leftist guerrilla movement with its origins in the urban middle class, was returning to politics and won the largest block of votes of any organized group at the constitutional convention.

Whether out of partiality for strong judicial enforcement of rights and other ruleof-law values, a need to keep the ex-guerrillas on board, or a general impatience with

3 Rodrigo Nunes, "Ideational Origins of Progressive Judicial Activism: The Colombian Constitutional Court and the Right to Health," Latin American Politics \& Society 52 (2010): 67-97. 
civil law-trained members of the Colombian legal elite - or, most likely, a combination of all these - Gaviria charged a group of young U.S.-trained lawyers to work as drafters alongside his U.S.-trained economists. ${ }^{4}$ Led by a future justice of that court, Manuel José Cepeda, these lawyers negotiated for an extensive battery of ESR in the constitution. The package of social-democratically inflected ESR was sufficiently comprehensive that the M-19 merely adopted the government's proposal, rather than putting forth their own set of demands. ${ }^{5}$ The result, as we shall see, is that Colombia now has a constitution with a neoliberal spine and a social democratic heart, enforced by one of the most ambitious and canny constitutional courts in the world. ${ }^{6}$

The Brazilian constitution was crafted a few years earlier, in 1988. Widely known as "the citizenship constitution,"7 it has less of the neoliberal impulse in it, but is equally founded on the hopes of various progressive groups that a robust constitution, including social and economic rights, might serve to bring Brazil's marginalized classes into full citizenship. Just as in Colombia, the 1988 Brazilian constitutional assembly included a number of former leftist guerrilla fighters who had put down their arms to enter politics in a world dominated by neoliberal economic thought. Just as in Colombia, these revolutionaries understood that they could perhaps gain, in this constitution-making moment of flux and uncertain transformation, important economic concessions that they could not win in the legislature. ${ }^{8}$ And finally, just as in Colombia, enthusiasm for ESR served as a bridge between the revolutionary left and the establishment liberals and moderates; for the latter saw the promise of a decent welfare state as an authentic aspiration of civilized, liberal modernity, a source of long-term social stability, and a way to bring the revolutionaries on to the civilizing plane of parliamentary politics and lawmaking. The Brazilian judiciary went on to forge a jurisprudence of constitutional social rights on the basis of the 1988 Constitution; the nation's courts, as we will see, would become central actors in decision making around basic goods like health care. ${ }^{9}$

Other examples of social constitutionalism abound. Even in Argentina, where the basic constitutional text dates back to an earlier era, amendments in 1994

4 Ibid. The president's disillusionment with Colombian civil law-minded attorneys trained in Spain was highlighted as an explanation for this recruitment of young U.S.-trained lawyers in the authors' personal conversation with Manuel Jose Cepeda on February 13, 2012.

5 Ibid.

6 M. J. Cepeda, "The Judicialization of Politics in Colombia: The Old and the New," in The Judicialization of Politics in Latin America, ed. R. Sieder, et al. (Palgrave Macmillan, 2005): 67-103. See also Nunes, "Ideational Origins of Progressive Judicial Activism."

7 In Portuguese it is known as "a constituição cidadã," which loosely translates as the citizen constitution or citizenship constitution.

8 Personal conversation, William Forbath with Nelson Jobim, August 2011.

9 F. Hoffman and F. Bentes, "Accountability for Social and Economic Rights in Brazil," in Courting Social Justice: Judicial Enforcement of Social and Economic Rights in the Developing World, ed. V. Gauri and D. M. Brinks (Cambridge University Press, 2008), 100-45; Flavia Piovesan, "Brazil," in Social Rights Jurisprudence: Emerging Trends in International and Comparative Law, ed. Malcolm Langford (Cambridge University Press, 2009), 182-91. 
incorporated many ESR explicitly and then, for good measure, incorporated by reference all the rights included in all human rights treaties to which Argentina is party, including the International Covenant on Economic, Social and Cultural Rights (Article 22). Costa Rica has long included labor rights, but in the 1990 also included international human rights (including ESR) and environmental rights, among others, in the repertoire of rights enforceable through the amparo mechanism. The successful Nicaraguan revolutionaries, the Sandinistas, drafted Nicaragua's 1987 constitution to include a full set of social rights, from health, to housing, to working conditions. Mexico's constitution continues to fall in this camp. In general, one is currently hard-pressed to find a constitution in Latin America that does not contain a robust set of economic and social rights.

\section{THE ACTUALLY EXISTING WELFARE STATES}

And yet, at the same time as constitutional texts were expanding and entrenching formal welfare rights, the welfare states in the region were coming under increasing pressure from neoliberal reforms. As we have glimpsed, the pioneers of welfare-statebuilding in early twentieth-century Latin America had been more or less authoritarian populist regimes with a narrow, urban, unionized base of support. As a result, these welfare states tended to reinforce as much as ameliorate socioeconomic inequalities, targeting the urban formal sector of the labor market and largely ignoring the vast rural and urban informal sectors. The results were social welfare states that were "deep but not wide." ${ }^{10}$ Even the more democratic countries focused largely on workers in those industries essential to the mid-century economic development strategy that went under the banner of import substitution industrialization (ISI). In both cases, then, state provision was often tied to labor unions and therefore, by definition, limited to the formal sector. ${ }^{11}$ To make matters worse, labor market rigidities led to the dramatic growth of the unprotected informal sectors of nations' labor markets, ${ }^{12}$ leaving large numbers of people utterly outside whatever kinds of labor standards, social goods, and social insurance were on offer from the welfare state. Brazil is a case in point. As late as the mid-1980s, when the dictatorships were beginning to collapse, as many as 80 percent of Brazil's rural workers, and up to

10 Stephan Haggard and Robert R. Kaufman, Development, Democracy, and Welfare States: Latin America, East Asia, and Eastern Europe (Princeton University Press, 2008), 5, 12, 79. See also Eric Hershberg, et al., Latin America after Neoliberalism: Turning the Tide in the 21st Century? (New Press, 2006), 4-5

11 Ibid., 64

12 Ibid., 63. See also Marilyn Carr and Martha Alter Chen, "Globalization and the Informal Economy: How Global Trade and Investment Impact on the Working Poor," paper commissioned by the International Labor Organization (2002), 1, available at http:/www.ilo.org/global/publications/lang-en/ index.htm (noting that, by the 1990s, the nonagricultural informal sector accounted for about 55 percent of the workforce in Latin America). 
one-third of its urban informal workforce, were not even registered in the social security and pension systems, let alone receiving any benefits. ${ }^{13}$

At this constitutional crossroads, however, between the final decade of the old authoritarian regimes and the dawn of the new democratic orders, even the narrow and unequal Latin American welfare state came under fierce attack. Reigning economists on the national and international scenes, international financial organizations, and financial elites, public and private, all blamed ISI and the welfare state for much of the 1980s debt crises and hyperinflation. The Washington Consensus famously enjoyed greater sway in 1980s Latin America than it did among domestic policy makers in 1980s Washington. So, in Latin America, ISI was dismantled and welfare states dramatically rolled back. And yet, the trickle down prosperity that the Washington Consensus promised did not come. Instead, as social provision declined, inequality increased, and poverty became an increasingly acute problem.

Moreover, with democratization, poverty had acquired a great deal more political bite. The new liberal democratic orders rested on a far broader social base than had the dictatorships. The informal sector, the urban poor, indigenous groups, and hardhit rural populations all became electorally relevant in the aftermath of democracy. From all these quarters, demands for public social provision mounted. And for progressive activists throughout the region, the ESR of the new democratic constitutions beckoned like official promissory notes. Much as the more left-leaning constitutional drafters had hoped and promised, the ESR-bearing constitutions, the "citizenship constitution," might be the platform for demanding that the state and polity actually take up the long-deferred project of distributive justice.

In the end, the neoliberal project failed, in Latin America as in many of the MICs, to produce prosperity for all, and the constitutional aspiration for social citizenship has proved to demand a far more conscious and arduous ESR politics. The perceived failure of the Washington Consensus, however, and its rejection by many Latin American state elites, has given ESR politics an unexpected boost. State economists, planners, and policy makers have turned away from rigid free market orthodoxy (or, as in Brazil, found their opposition to much of that orthodoxy confirmed) over the past decade. The region has seen a marked shift toward models of the "new developmental state," or what some have called "Latin American neostructuralism." 14 The new developmentalism, according to David Trubek and his collaborators, ${ }^{15}$ represents an emerging, but still uncertain and unsettled, marriage of key features and insights of neoliberalism, on one hand, and some of the

13 Kurt Gerhard Weyland, Democracy without Equity: Failures of Reform in Brazil (University of Pittsburgh Press, 1996), 134-5.

14 Leiva, Latin American Neostructuralism. See also David M. Trubek, "Developmental States and the Legal Order: Towards a New Political Economy of Development and Law," Discussion Paper No. 1075 (Wisconsin Law School, 2009).

15 Ibid. See also David M. Trubek, et al., "Toward a New Law and Development: New State Activism in Brazil and the Challenge for Legal Institutions," The World Bank Legal Review (2012), 281-314. 
premises and arrangements of the older tradition and institutions of state-led developmentalism, on the other. It also borrows from the "new governance" models afoot in the North. ${ }^{16}$ Thus, like neoliberalism, the new developmentalism abjures direct state ownership of industry and is relatively open to imports; it emphasizes making national firms competitive rather than shielding them from competition. Likewise, new developmentalism aims to cultivate local entrepreneurship and innovation, rather than relying on imported technology and know-how. At the same time, however it envisions a robust role for the state in steering and coordinating industrial development, promoting globally competitive "national champions" and underwriting education, research and development, and technological innovation. It makes heavy use of public-private partnerships in everything from information sharing and regulatory regimes to infrastructure investments. In sharp contrast to neoliberal orthodoxy, new developmentalist-minded state actors believe that government can "pick winners," at least in regard to industrial sectors. There remains much debate about how much of the new developmentalism represents a genuinely important array of innovative new policies and institutional arrangements, and how much it is merely a new rhetoric that may mask an older set of state practices, subsidizing already well-established industries with strong political influence. One thing, however, is certain: both at the level of rhetoric and in their real-world policies and practices, new developmentalism-minded state elites in Brazil, Colombia, and elsewhere have embraced the idea that social solidarity matters, inequality must be reduced, and ending mass poverty and including the rural and urban dispossessed in the social enterprise are not only moral or political issues but matters of long-term growth and economic health. Brazil's expanding and expansive Balsa Familia is a famous case in point.

To be sure, the Washington Consensus in many of its iterations used the language of "investing in human capital"; but in this case, it is the new developmentalists who are practicing what was often just preaching by supporters of the Washington Consensus. ${ }^{17}$ On their account, assuring a decent minimum of goods like food and water, health, housing, and education are no longer the hoped-for results of good economic policy, but instead are essential ingredients of it. What the ESRminded lawyers call the "progressive realization of social and economic rights," the "new developmentalist" economists call "investing in human capital" and "human development" as "a critical input into expanding economic growth." 18

16 Trubek, "Developmental States and the Legal Order," 24-5.

17 See Peter Evans and Patrick Heller, "Human Development, State Transformation and the Politics of the Developmental State," in The Oxford Handbook of Transformations of the State, ed. Stephan Leibfried, et al. (Oxford Press, forthcoming).

18 Peter Evans, "The Capability Enhancing Developmental State: Concepts and National Trajectories." Paper presented at the UNRISD-KOICA conference (2011), on file with authors, available at http:// www.proac.uff.br/cede/sites/default/files/TD63.pdf. See also Michael Boozer, et al., "Paths to Success: The Relationship between Human Development and Economic Growth" Discussion Paper No. 874 (Economic Growth Center, Yale University, December 2003), cited in Evans, "The Capability Enhancing Developmental State." 
To be sure, efficiency-minded state economists can be expected to be leery of the seeming absolutism of rights talk. Still, the ESR provisions of the new constitutions have acquired a new salience in the corridors of state power. What is more, there is a surprising measure of antiformalist, contextualized, pragmatic, and policy-oriented thinking in the ESR jurisprudence of some Latin American constitutional courts. And so, as we will see, for example, in the case of Colombia's health care litigation, a new space seems to have opened up for commerce between such courts and reformminded technocrats in the administrative state elites.

\section{ECONOMIC AND SOCIAL RIGHTS ADVOCACY AND ADJUDICATION - EXPERIENCE IN THE COURTS, STATES, AND POLITIES OF MIDDLE-INCOME COUNTRIES OF LATIN AMERICA}

When long lists of ESR began appearing in the new constitutions of MICs in Latin America and elsewhere, the idea of taking such rights to court generally found a skeptical, even hostile, reception, as much among scholars and activists on the left as among traditionalist judges. Skeptics posed many practical objections - that ESR advocacy was an antipolitics, a diversion of resources and energy from the necessary tasks of movement building and political engagement, and required an unwarranted faith in the policy-making capacity and coercive power of courts. In addition, the notion of "judicializing" ESR has met with principled objections. Under democracy, the meaning and content of new ESR commitments - what does it mean to ensure a right to education, or decent housing, health care, or employment; and how should resources be allocated and priorities set? - are questions whose technical dimensions require the expertise of policy professionals and whose normative dimensions should be addressed in the polity, through the active engagement of the citizens for whom ESR were enacted. ${ }^{19}$

Unifying many of these critiques was an image of what ESR advocacy and adjudication was destined to look like. "ESR-based demands" would become the subject of purely legal battles, waged solely in courtrooms, and entrusted to legal and social elites. Judicial victories, when and if they arrived, would mean government by judicial decree: courts would issue nonnegotiable, absolute demands that must be satisfied to their fullest extent, without consideration of their broader institutional or allocative impact. More often than not, however, events have given the lie to such conventional images of "judicialization."

The real work of reforming and building welfare policies on the basis of ESR demands is robustly political; it engages the dispossessed, would-be ESR-bearing

19 Jeremy Waldron, "A Rights-Based Critique of Constitutional Rights," Oxford Journal of Legal Studies 13 (1993): 18-51; Frank B. Cross, "The Error of Positive Rights," UCLA Law Review 48 (2001): 857; Ran Hirschl, Towards Juristocracy - The Origins and Consequences of the New Constitutionalism (Harvard University Press, 2004); Gerald N. Rosenberg, The Hollow Hope: Can Courts Bring about Social Change?, 2nd ed. (University of Chicago Press, 2008). 
citizenry; and the courts' response has been, in many cases, more nuanced than many expected. Contrary to the stylized "juristocratic" vision sometimes presented, ESR movements across the world pursue a comprehensive rights-based mobilization strategy in which social movements work in tandem with courts and other legal actors, at the same time that they continue to work the streets and legislative hallways. Courts are often central actors, but rather than issuing imperious, detailed decrees, they often choose to engage all the relevant parties in extensive and productive dialogue around concrete problems until new policy solutions are worked out. ${ }^{20} \mathrm{We}$ will develop these two points in their turn.

The first point is that the typical domestic ESR movement looks very different from the "juristocratic" model on which many critiques are based. The vocabulary of ESR enshrined in constitutions and conventions imbues the language of these social movements, and the strategies certainly include litigation. But the latter is often not the primary focus of the various actors, even in countries like Brazil, where certain rights, like the right to health, have been thoroughly judicialized. ${ }^{22}$ In many rights-based campaigns judicial action is subordinate to and at the service of political action. Lawsuits support mobilization; fill in gaps; generate greater oversight of bureaucrats and policy makers; provide leverage to ESR movements' allies and collaborators in the legislature, the technocracy, and the party and administrative state elites; and encourage the wedding of the technocratic, efficiency-based rationality wielded by state elites to constitutional ESR commitments and normative reasoning. There is nothing apolitical or demobilized about these movements.

Take, for example, the right to health movement in Colombia, which secured one of the more ambitious judicial orders in this area. The Colombian legal system was being flooded with hundreds of thousands of individual claims for violations of the right to health. ${ }^{23}$ The Court processed these hundreds of thousands of individual claims in a fashion that generated a right to health movement, new NGOs, and massive grassroots support for the Court's activism. The Court's generous responses to individual tutela actions led - predictably enough - to enormous hostility on the

${ }^{20}$ Gauri and Brinks, Courting Social Justice; Daniel M. Brinks and William E. Forbath, "Social and Economic Rights in Latin America: Constitutional Courts and the Prospects for Pro-poor Interventions," Texas Law Review 89 (2011): 1943; Lucie White and Jeremy Perelman, Stones of Hope: How African Activists Reclaim Human Rights to Challenge Global Poverty (Stanford University Press, 2011); William Forbath and Geoff Budlender (with assistance from Zackie Achmat and Mark Heywood), "Cultural Transformation, Deep Institutional Reform, and ESR Practice: South Africa's Treatment Action Campaign," in White and Perelman, Stones of Hope; Varun Gauri and Daniel M. Brinks, "Human Rights as Demands for Communicative Action," Journal of Political Philosophy (2012): 407-31.

${ }^{21}$ See Ran Hirschl, Towards Juristocracy - The Origins and Consequences of the New Constitutionalism (Harvard University Press, 2001).

22 Hoffmann and Bentes, "Accountability for Social and Economic Rights in Brazil."

23 Alicia Ely Yamin, et al., "Colombia - Judicial Protection of the Right to Health: An Elusive Promise?," in Litigating Health Rights: Can Courts Bring More Justice to Health?, ed. Alicia Ely Yamin and Siri Gloppen (Harvard University Press, 2011), 103-31. 
part of key figures on the executive branch, which responded with a number of emergency decrees. The president's decrees set out to quell the Court's solicitude for the right to health by imposing spending constraints and shutting down access to the Court in the name of safeguarding the solvency of the public health system. Broadly unpopular as well as legally dubious, the president's intervention triggered mass protests and even more public mobilization around the right to health. Protesters carried placards declaring "A Tutela Saved My Life." 24 ESR attorneys brought a challenge to the president's intervention to the Constitutional Court, garnering no less than 1,200 amicus briefs by many grassroots organizations and unions. ${ }^{25}$

Buoyed by popular support, the Court overturned the president's actions. Revealingly, however, the Court also stepped away from its previous path of simply liberally granting individual tutela claims. Instead, the Court married its overturning of the presidential decrees to a structural reform decree of its own. Rather than spurning the executive branch's worries about budgetary chaos, the Court took the fiscal problems seriously. It refused to simply decree a reformation of the public health care system that met the demands of right to health advocates, but it insisted that the new social movement's activists, attorneys, and reform-minded public health experts have a seat at the table, where structural reforms would be hammered out under the Court's prodding and supervision.

In the process, the Court summoned the nation's financial ministry and social budget officials along with the heads of the various key elements of Colombia's disjointed health care system to appear before it. And with a canny sense of where the state's most reform-minded technocrats were to be found, it put them to work, demanding what the state's isolated and arthritic bureaucracies had never produced: a systematic cost accounting of the public health system's budget and performance. With this accounting in place, both the court and the bureaucrats were finally in a position to truly gauge how much the system's notorious disjointedness and inefficiencies were to blame for its shortcomings, and how far the shortfall really was between current budgetary allotments and the right to health care advocates' account of a minimally adequate system of health care provision. More startlingly, the Court also directed the ESR advocates and their experts and the state officials and technocrats to collaborate and bring back to the Court a plan for the merger and cross-subsidization of the hitherto separate schemes of free public health care available to the poor and the contributory health care system available to those who can pay. ${ }^{26}$

Here, the Constitutional Court was taking a leaf from the new developmentalist economists' playbook. Old-fashioned social democratic health care thinking leaned

24 Julieta Lemaitre and Katharine Young, "The Comparative Fortunes of the Right to Health: Notes from Columbia and South Africa," unpublished manuscript, p.13, on file with author.

25 Ibid.

26 See Corte Constitucional [Constitutional Court of Colombia], July 31, 2008, Sentencia T-760/08 (Colom.). 
toward free and universal coverage; that was the ideal of a social right to health. In a post-welfare state world, the human development-minded strains of neoliberal social policy have evolved more sophisticated, hybrid ideas. Among these are "responsibilizing" poor people by making them "coproducers" of and "active participants" in their own health care (i.e., maintaining certain kinds of copayments and disciplinary conditions on public health care provision), while also merging the old bifurcated systems of free and contributory health care. This way, one can bring the resources as well as the cost controls of the former to bear on the latter, and use cross-subsidization to provide a fuller measure of health care for the poor, in the process assuring one of the key ingredients of long-term economic growth. To put it in the Colombian Constitutional Court's rubric, "[e]fficiency and financial sufficiency are not necessarily incompatible with solidarity." 27 The economists' and technocrats' tools and touchstones could be put in the service of the constitutional mandate of progressive realization of the social right to health.

In general, the Court's intervention was a far cry from a judicial decree commanding the state to fully fund a public health care system that measured up to a human rights advocate's standards; it called for blending such standards with economists' measures, and left open how the two would be combined, and whether the Court would demand or the state cooperate with cashing out a decent minimum of health care coverage for poor citizens. All this remained up for grabs, in the internal dynamics of the peak-level policy negotiations over which the Court presided, and in the polity, where the judicially buoyed right to health movement continued to mobilize and exert pressure. The proof of the pudding, thus far, has been an announcement by the president that his administration is going forward with a plan to merge the public and contributory branches of health care provision for the nation's children in the name of economy and solidarity, but without mention of the judicial prodding. ${ }^{28}$

As with the right to health, the Court has played an outsized role in empowering the "internally displaced persons" (IDP) movement and the activists and advocates representing the millions of citizens uprooted by the conflict. The IDP movement has pushed for adequate housing, education, health care, and basic support, and like the right to health movement, it has done so with a blend of litigation and political mobilization. As one participant describes it, the final hearing in the landmark IDP case before the Colombian Constitutional Court included three hundred "lawyers, activists, grassroots leaders, journalists, government officials, and academics," while the square outside was filled with protesters drawn from among the displaced persons. ${ }^{29}$ At issue in that case was not a single identifiable human rights violation,

27 Corte Constitucional [Constitutional Court of Colombia], February 2, 2003, Sentencia C-150/03, para. 4.5, quoted in René Urueña, "The Rise of the Constitutional Regulatory State in Colombia: The Case of Water Governance," Regulation and Governance 6 (2012): 282.

28 Personal conversation, Manuel Jose Cepeda, February 13, 2012.

29 César Rodríguez Garavito, "Beyond the Courtroom: The Impact of Judicial Activism on Socioeconomic Rights in Latin America," Texas Law Review 89 (2011): 1669. 
but what the Colombian Constitutional Court called "an unconstitutional state of affairs," the product of systematic failures on the part of the government to deal with the situation of the people rendered homeless and displaced by Colombia's violent internal conflict.

Once again, the Court did not attempt to decree a substantive solution. Instead, it called for hearings, reports, fact finding, and the design of new solutions by government officials and agencies. Using the individual tutelas or constitutional complaints of 1,150 displaced families as "diagnostics" of the systemic failures of government, the Court set about orchestrating and demanding a coordinated response on the part of all the social and governmental actors with an interest in the matter. Again, as with the right to health movement, the Court assured the IDP advocates a seat at the table and a significant portion of bargaining power. ${ }^{30}$

It is instructive to compare the interplay of social movements and Constitutional Court in the Colombian context with that in South Africa, another middle-income nation with great resources, vast inequality, a renowned Constitutional Court, and a progressive new constitution forged in the early 1990 and brimming with economic and social rights. As in Colombia, social movements of post-apartheid South Africa seized on the ESR language of the nation's new democratic constitution to frame their demands that government make good on the social transformation the new constitution promised for the nation's poor. As in Colombia and much of Latin America, in the late 1990 s and early 2000s, South Africa's ESR movements confronted an administration committed to a neoliberal political economy. Like their Latin American counterparts, Mandela's and then Thabo Mbeki's African National Congress (ANC) party policy-making elite envisioned a market-friendly path to social democracy. As the ANC's path failed to bring redistribution and new social goods for the mass of poor South Africans, poor South Africans did not abandon the party that had led the anti-apartheid struggle; instead, ESR movements became vehicles for popular rage and disappointment. And again, as in Colombia, ESR advocates found in the Constitutional Court a crucial ally in their efforts to push government for the realization of these rights, in the areas of social provision, health, housing, water, and other social goods.

What sets the two countries' social movement/Court collaborations apart from one another is the much less sweeping, more narrowly crafted, and gingerly role that South Africa's ESR movements have carved out for litigation - a far less central and commanding, less managerial role, matching the more circumscribed role that South Africa's Constitutional Court has insisted that the judiciary play in the service of realizing ESR. Court victories have not been the primary objects of ESR movement campaigns, but instead one important source of political leverage and moral authority to promote pro-poor policy changes and institutional reforms.

${ }^{\circ}$ Ibid. 
Take the Treatment Action Campaign (TAC), which arose in the late 1990 in response to the nation's tragic HIV/AIDS pandemic and the Mandela and then the Mbeki administrations' death-dealing refusal to implement any substantial HIV/ AIDS treatment or prevention programs in South Africa's public health sector. Many of the most seasoned and sophisticated organizers, activists, and advocates of the anti-apartheid era joined the movement for the right to health care for HIV/ AIDS sufferers, and they made the polity and local, national, and international public spheres the key arenas for TAC's right to health care claims. Movement and coalition building, policy proposals and political initiatives, publicity and lobbying as well as civil disobedience campaigns: all these were forged ahead of litigation strategy, and the latter was subordinate to them.

First, TAC took to the international stage, demanding affordable antiretroviral drugs (ARVs) for the nation's public health system using intensive, media-savvy campaigns (including gripping demonstrations at international financial institutions, and open defiance of laws against bringing generics to South Africa) against the pharmaceutical industry and the Clinton administration. Then, with concessions from both of these, the TAC sought out reform-minded provincial officials to undertake local rollouts and experiments, demonstrating that the drugs could be effectively administered in the rickety public health clinics; and it waited - staging public protests to dramatize HIV/AIDS's relentless toll - while the state's medical board assessed the medicine's alleged dangers, costs, and benefits.

When TAC finally brought its landmark case, it demanded only that the public health system roll out the single dosages of ARVs needed for prevention of motherto-child transmission of HIV. The lower court granted and the Constitutional Court upheld the decree TAC sought. In keeping with the Court's emerging ESR jurisprudence, the justices framed the issue as one concerning the "reasonableness" of government's refusal to roll out the simple medical regimen notwithstanding its de minimis cost and proved safety and effectiveness - both premises substantially attributable to the TAC's earlier groundwork. This refusal, the Court declared, violated the affected mothers' and babies' constitutional social right to health care.

Combining caution and boldness, the Constitutional Court's decision offered a distinctive vision of judicial collaboration with civil society organizations like TAC in the realm of ESR. The opinion offers a subtle account of the interplay of ESR claims and arguments in the polity and legal-constitutional interventions on the part of courts: the first a matter of organizations like TAC backing up claims of right with the exchange of views, information, and expert opinion between state and civil society using petitions, proposals, reports, conferences, joint commissions, hearings, and negotiations; the second a matter of the courts keeping the civil society/state exchanges and negotiations open and vital, and prodding and compelling the state when it falls short of its procedural or substantive constitutional duties and commitments. 
The Court was also at pains to stress the limits of its role. It refused, as it already had in Grootboom, an earlier landmark right to housing decision, to hammer out the content of a "minimum core" definition of the right to basic health care, in the HIV/ AIDS context, or any other. The UN Committee on Economic, Social and Cultural Rights had endorsed and adopted the "minimum core" idea, as a way of giving substance and direction to national ESR efforts and adjudications. But the Court rejected the notion: demanding, charting, and hammering out the evolving, substantive content of the constitution's ESR were tasks that belonged to civil society and the legislature and executive branches. The judiciary's main contribution would be a more traditionally legal, process-based one: to "guarantee that these democratic processes" through which deliberation, debate, and contestation over the achievement of ESR "must unfold ... are protected to ensure accountability, responsiveness and openness.”

As far as the substantive content of policies was concerned, the judiciary's role was simply to demand, as it did in the TAC case, that government explain and justify its actions when these are challenged. The South African Constitutional Court made plain in TAC and subsequent cases that it has no stomach for the kind of magisterial judicial oversight of ongoing processes of policy formation or state building that the Colombian Court has embraced. As South African Constitutional Court Justice Yvonne Mokgoro observed recently, even - or perhaps especially - a committed social democratic judge must recognize that litigation "tends to be the privilege of the economically empowered"; therefore, a "vigilant civil society" must "agitate for change and monitor implementation" using "more accessible and direct strategies." 31

This was how TAC finally pushed the South African state and the obdurate ANC leadership to roll out a full-blown HIV/AIDS program in the public health system: agitation and disobedience, politicking, policy making in collaboration with sympathetic high state and party officials, and monitoring - invoking the Court's ringing affirmation of the right to health care for HIV/AIDS sufferers, but keeping litigation in a backup role.

\section{WHY COURTS?}

In light of the indispensable role of social mobilization, agitation, politicking, policy making, and monitoring to ESR movements, then, why are the courts occupying as much space as they do in the ESR movements' repertory? Why not simply go into the streets, or lobby for more generous policies? The first answer is that courts sometimes break open stalemated politics and provide wedges into authoritarian power structures. One of the foremost practitioners of ESR litigation in Argentina

\footnotetext{
${ }^{31}$ Yvonne Mokgoro, "Constitutional Claims for Gender Equality in South Africa: A Judicial Response,"
} Albany Law Review 67 (2003): 565-6. 
argues that the need for litigation grows as the space for political participation shrinks. ${ }^{32}$ Unfortunately, democratization has sometimes not been followed by a truly pluralistic and open politics. In some cases, due in part to constitutional and electoral system design, we observe a drift toward a quasi-one-party state. South Africa is a case in point, where the constitutional vision of open, responsive, deliberative, and participatory democratic state and party institutions are not to be found within the executive and legislative branches or in the party political apparatus. Rather, it has fallen to the social movements, civil society organizations, the press, and the judiciary to challenge these failures. For the "new South Africa," the courts and the public sphere of social rights advocacy have become the spaces for accountability through opposition politics and participatory and deliberative policy making. In other cases, representative politics are hampered by corruption and incompetence. When political roadblocks exist that are preventing the expression of widely felt demands, courts can sometimes become the spaces for contestation and deliberation that cannot be found in the other branches of government.

Moreover, courts are often called in because of some shortcoming or weakness in the administrative state. In Brazil, patient groups use litigation to sue for more up-to-date treatments, arguing that the agency in charge of updating the public health offering is failing to keep up with advances in medical technology. ${ }^{33}$ Other times, they act to ensure that frontline bureaucrats are carrying out the legislative mandate and national policy 65 percent of the drugs being demanded through litigation in Brazil are on the approved list, but patients are unable to secure them. ${ }^{34}$ In Colombia, until the major decision in 2008 that sought to completely restructure the public health system, ${ }^{35}$ the vast majority of the tens of thousands of cases seeking medical treatment and medications were demands for goods and services that were already included in legislated mandates, and that should have been supplied by the private providers who were being sued..$^{6}$

Other times, the demands focus on extending universal promises to neglected and stigmatized groups that cannot at first get a hearing. In country after country, AIDS activists spearheaded the movement for legal enforcement of health rights. ${ }^{37}$ The

${ }^{22}$ Centro de Estudios Legales y Sociales, La Lucha por el Derecho (Siglo Veintiuno, 2008), 13. See also ibid., 25 .

33 Hoffman and Bentes, "Accountability for Social and Economic Rights in Brazil."

${ }^{34}$ João Biehl, et al., "Between the Court and the Clinic: Lawsuits for Medicines and the Right to Health in Brazil," Health \& Human Rights 14 (2012): 1.

35 Corte Constitucional [Constitutional Court of Colombia], July 31, 2008, Sentencia T-760/08 (Colom.).

$3^{6}$ Yamin, et al., "Colombia - Judicial Protection of the Right to Health"; Yamin and Gloppen, Litigating Health Rights; Alicia Ely Yamin and Oscar Parra-Vera, "Judicial Protection of the Right to Health in Colombia: From Social Demands to Individual Claims to Public Debates," Hastings International \& Comparative Law Review 33 (2010): 431.

37 Gauri and Brinks, eds., Courting Social Justice; Hoffmann and Bentes, "Accountability for Social and Economic Rights in Brazil"; Magdalena Sepúlveda, "Colombia," in Social Rights Jurisprudence: Emerging Trends in International and Comparative Law, ed. Malcolm Langford (Cambridge University Press 2009), ch.7. 
groups carrying the ESR banner are often the most marginalized: rural-indigenous, landless, roofless, the informal working sector. This is perhaps clearest in the many rights-based movements for land and dignified housing. In Latin America the propoor right to land movement is strongly radicalized. In Brazil we find the right to land mobilized by the Movimento Sem Terra, the Movement of the Landless, and the right to housing deployed by the Movimento dos Sem Teto, the Movement of the Roofless. ${ }^{3}$ In Argentina, we see similar rights-based language mobilized by the squatter movement - a loosely organized network of groups that occupy residential buildings and factories, collectively known as Okupas, or Occupiers, claiming legitimacy under the right to work and the right to housing. These groups have only rarely turned to the courts, but over the past two decades, since the creation of the new constitutions, they have turned from older discourses of religious and revolutionary protest to framing their demands in the language of ESR. Even those who have not gone to court have gained a new sense of legitimate entitlement and claims on the state, in virtue of the new constitutions' inclusive promises to the poor and dispossessed and the efforts of advocates, jurists, and ESR-minded state elites to realize them.

This last discussion highlights one important change from the politics of the traditional welfare state in Latin America: the politics of ESR includes groups far removed from the world of traditional beneficiaries, of formal sector, unionized workers. To be sure, many of the movements are rooted in urban, middle-class groups with a common interest - say a particular illness, or a desire to see urban green spaces protected. But many more are explicitly anchored in marginalized and excluded groups: the poor, the hungry, the homeless. In both cases, claims on the state tend to be channeled, in whatever broad and collective or narrow, individual shape, through attorney advocates.

Thus claimants engage the state's legal apparatus in a variety of ways. They rely on litigation and extensive informal contacts with key judges to shape jurisprudence; and they provide crucial agendas and constituencies for courts interested in bringing constitutional ESR to earth using a broad reach into social policy. They engage with public prosecutors in places like Brazil, where the Public Ministry has a broad portfolio that includes the realization of constitutional rights, and with ombudsmen's offices and national human rights commissions elsewhere. They also develop ad hoc partnerships with political entrepreneurs and parties in order to advance common goals. They are not tied to any particular party, but they often do work with politicians to propose bills and advance policy objectives, turning to the courts often only as a last resort. ${ }^{39}$

$3^{8}$ The full name of these two movements often includes a reference to "the workers" - Movimento dos Trabalhadores Rurais Sem Terra, and Movimento dos Trabalhadores Sem Teto - but they are most often referred to simply in terms of what they lack - land, a roof.

39 Daniel M. Brinks and Varun Gauri, "A New Policy Landscape: Legalizing Social and Economic Rights in the Developing World," in Gauri and Brinks, Courting Social Justice, 303-52. 
What has been the overall shape of the courts' response to these growing demands? If, as we have suggested, courts are often at the center of clashes over the contours of an ESR-based welfare state, still, different courts have responded to the challenge in very different ways. These differences in turn have had much to do with the subsequent texture of welfare state politics, sometimes more juriscentric, as in Colombia; sometimes more multifaceted, as in South Africa; and sometimes joining individual vindications through the courts with more concerted action in the legislature, as in Brazil. Different legal traditions, judicial attitudes, and modes of decision making both determine and take shape from these disparate ESR movement strategies and approaches.

We can map the various courts' decision-making styles along two dimensions. The first dimension concerns judicial deference versus assertiveness toward the legislature and the executive branch; it involves what constitutional lawyers call "separation of powers"; and it runs along the path between what is often called "judicial restraint" versus "judicial activism." The second dimension looks at styles of judicial reasoning. It concerns the contrast between what jurisprudes and legal theorists call "formalism" versus "pragmatism" or "policy" and "purposive" reasoning. "Formalist" judges present their judgments as logical, even syllogistic deductions from the legal or constitutional provisions at hand applied in a more or less mechanical fashion to the facts of the case. "Pragmatist" judges, by contrast, tend to acknowledge that logical deductions from the often highly general, open-ended phrases in the constitutional text (like the "right to health" or the guarantee of "freedom of speech") cannot decide concrete cases; instead, pragmatist judges reason in a more or less openly policy-minded and value-laden fashion, having regard to the "underlying purposes" and "principles" animating the legal or constitutional text, and also taking account of the broader, systemic consequences of their rulings. The "pragmatist" judge is more comfortable, for example, discussing the allocational trade-offs that inevitably attend decisions about ESR; and she is more at home crafting collective remedies to address collective problems. But notice: there is no necessary connection between a court's outlook regarding judicial deference versus activism, on one hand, and its style of reasoning, on the other. The courts and cases we have used as examples herein can be arrayed along these two dimensions (see Table 11.1).

Thus, for example, both South Africa's and Colombia's Constitutional Courts employ a style of judicial reasoning that falls on the pragmatic side of the spectrum. The South African Court is somewhat more candid than its Colombian counterpart about the inescapably value- and policy-laden nature of constitutional adjudication and the extent to which decisions about ESR cannot be derived through formal reasoning from the text or the factual record. Yet, on our other dimension, as we have seen, South Africa's Constitutional Court is substantially more restrained and deferential toward the legislative and executive branches than Colombia's Court. 
TABLE 11.1. Judicial Decision-Making Models in ESR Cases

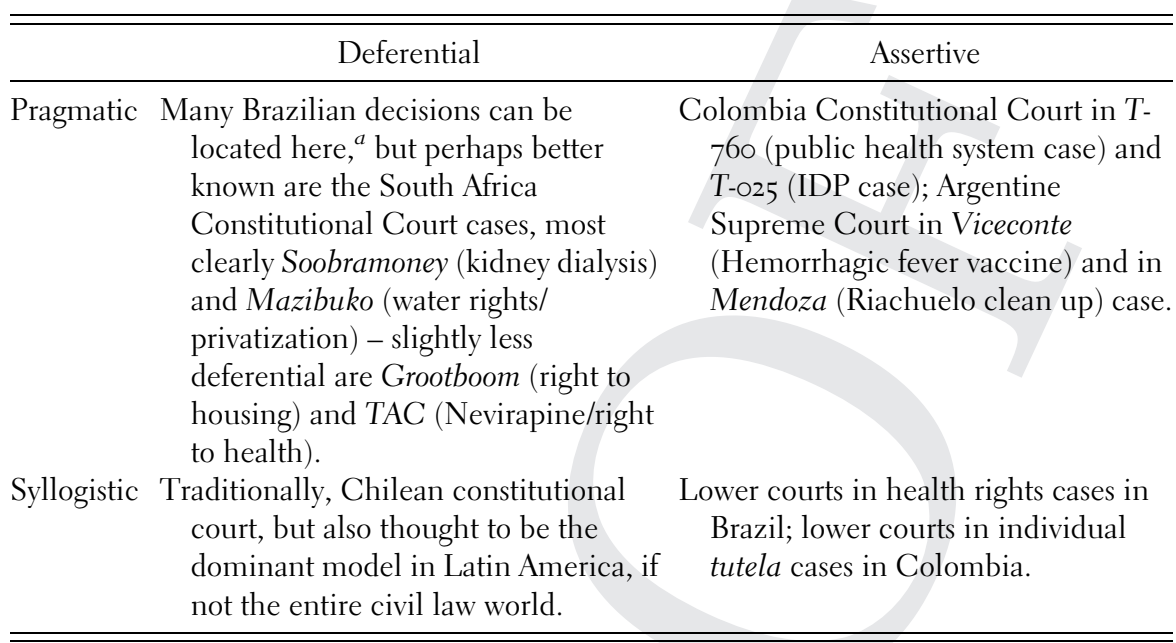

${ }^{a}$ Source: Diana Kapiszewski, High Courts and Economic Governance in Argentina and Brazil (Cambridge University Press, 2012).

Traditionally, Latin American courts were seen as the very model of syllogistic reasoning and deference toward the executive branch. ${ }^{\circ}$ As Javier Couso and Elisabeth Hilbink describe the traditional approach of the Chilean Constitutional Court, "[f]rom early in the country's republican history, Chilean judges were trained to be slaves of the law, but in a context in which law, particularly public law, was understood as the will of the executive." 41 Such a combination is unlikely to produce a court that will function as an effective ally in battles to reform and expand welfare provision. More recently, however, across Latin America, the courts of Mexico, Costa Rica, Peru, Colombia, Brazil, Argentina, and even Chile, to some degree, have become more assertive. Some, like the Colombian Court, have also adopted a broader policy-oriented mode of reasoning, while others have limited themselves to a more syllogistic style of decision making. ${ }^{4^{2}}$ The combination of assertiveness and pragmatic, policy-style reasoning signals a more wholehearted adoption by judges of their central role in the construction of a new welfare state. One can see this most

$4^{\circ}$ Keith S. Rosenn, "The Protection of Judicial Independence in Latin America," Inter-American Law Review 19 (1987): 1-35.

${ }^{41}$ Javier Couso and Elisabeth C. Hilbink, "From Quietism to Incipient Activism: The Institutional and Ideational Roots of Rights Adjudication in Chile," in Courts in Latin America, ed. Julio Rios-Figueroa and Gretchen Helmke (Cambridge University Press, 2011): 99-127.

$4^{2}$ See the discussion by Miguel Schor of the move from a syllogistic approach to one that engages in the balancing of competing considerations, which is conceptually related to the one we describe here, though restricted to the form of legal reasoning deployed by the judges in their decisions. Miguel Schor, "An Essay on the Emergence of Constitutional Courts: The Cases of Mexico and Colombia,” Indiana Journal of Global Legal Studies 16 (2008): 173-94. 
clearly exemplified, in its robustly assertive variant, by the Colombian Constitutional Court.

This Court, regarded by many other courts in Latin America as a leader in ESR jurisprudence, has developed a series of key concepts that give it the latitude to play a central role in developing the new welfare state. The first is reliance on the figure of a "mínimo vital" - or minimum requirements for a dignified existence ${ }^{43}$ - a notion loosely related to the "minimum core" idea fashioned by the UN Committee on Economic, Social and Cultural Rights and spurned, as we saw, by the South African Constitutional Court. This concept allows the Colombian Court to unmoor its rulings from specific language and provisions in the constitution, tying them instead to a broad view of what is necessary to give all human beings, including the poor and the politically marginalized, full human agency and social membership. ${ }^{44}$ While it would be impossible to catalogue here all the disparate claims that have emerged under the sign of ESR, this is the idea that ties them all together - states are required to, and can be compelled to, create the conditions that enable all individuals to gain access to full social and political membership and a dignified existence.

In its pursuit of that goal, the Columbian Constitutional Court has developed another crucial doctrine, that of the "unconstitutional state of affairs." Under this rubric, the court can identify a general condition that fails to live up to the robust promises of the constitution, even if it is not clear that anyone in particular, much less any individual state actor, is directly responsible for a constitutional violation. We encountered the doctrine in the IDP litigation described previously. The Columbian Constitutional Court has applied the doctrine in a variety of cases, not all of them of transcendental significance: "Since 1997, the court has handed down seven decisions of this kind, in greatly varying circumstances including noncompliance with the state's obligation to affiliate numerous public officials to the social security system, massive prison overcrowding, lack of protection for human rights defenders, and failure to announce an open call for public notary nominations." 45 The Columbian Constitutional Court, then, has crafted a powerful doctrinal grounding for embarking on broad policy-making and state-building projects: a broad normative basis - "human dignity"; an abstract and malleable substantive standard - "mínimo vital"; an expansive notion of constitutional harms - an

43 Sepúlveda, "Colombia." See also Rodolfo Arango and Julieta Lemaitre, eds., Jurisprudencia Constitucional sobre el derecho al mínimo vital [Constitutional Jurisprudence about the right to minimum subsistence] (Ediciones Uniandes, 2002).

44 Other courts also anchor their jurisprudence in this idea of human dignity: "Thus, from human dignity all other rights stem, insofar as they are necessary for man to integrally develop his personality.' Dignity means that individuals have 'the right to choose, in a free and autonomous manner, their life project. ... Hence, the recognition of the right to the free development of one's personality." Alejandro Madrazo and Estefanía Vela, "The Mexican Supreme Court's (Sexual) Revolution?," Texas Law Review 89 (2012): 1863, quoting a 2006 Mexican Supreme Court amparo decision on rights of transgendered people.

45 Garavito, "Beyond the Courtroom," 1670 , citations omitted. 
"unconstitutional state of affairs"; and relaxed standing requirements - thanks to the tutela, anyone can file a constitutional claim, and the court can then aggregate claims in any way it pleases in order to craft a case, not to mention its powers of abstract review.

Meanwhile, in South Africa, we have seen how the normative and strategic outlook on the part of social movements and ESR advocates has shaped and been shaped by the South African Constitutional Court's own somewhat more deferential conception of its role in respect of social rights. ${ }^{46}$ For various reasons, the South African Constitutional Court approach is one of gingerly prodding and monitoring government along both procedural and substantive lines. Thus the South African Constitutional Court and the High Courts have condemned and forced changes in the government's social-policy-making processes in service of greater transparency and participation and greater attention to the needs and demands of the nation's poorest citizens; and they also have condemned and forced changes in the substantive content of those policies, in service of the constitution's command that government take reasonable steps to realize citizens' social rights. Some of the High Courts have been more forthcoming than the South African Constitutional Court with ESR-based structural decrees ordering the development of new plans, programs, and policies, as well as orders forbidding evictions of squatters and cutoffs of water.

In what seems like a less promising approach, the Brazilian courts have prompted what detractors have labeled an "epidemic" of health rights litigation, without ever stopping to consider why so many individual cases are being filed, how the accumulation of individual decisions might affect the public health system, or how it might address the issue in a more systemic way. This has prompted critiques that its decisions shift the provision of public health toward the better off. ${ }^{47}$ The courts have largely disregarded the government's protestations that they should take into consideration fiscal constraints, the individual (let alone the cumulative) impact of these decisions on the broader public health system, or even the established process for determining the safety and appropriateness of particular medications and treatments. In case after case, they defer entirely to the decision of the treating physician, so that all that is required to succeed is a prescription. ${ }^{8}$ Some of this may be changing in the wake of a decision by the Supremo Tribunal Federal (Brazil's highest constitutional court) that purports to introduce public policy considerations, and set a sliding scale standard for deciding these cases ${ }^{49}$ but it is fair to say that the dominant model is still as described previously.

$4^{6}$ The South African Constitutional Court has recently become more deferential and has come under fire for abdicating its role in ways in which it had not been criticized before.

47 Octavio Luiz Motta Ferraz, "Harming the Poor through Social Rights Litigation: Lessons from Brazil," Texas Law Review 89 (2011): 1643.

$4^{8}$ Ibid.; Hoffman and Bentes, "Accountability for Social and Economic Rights in Brazil."

49 See Brinks and Forbath, "Social and Economic Rights in Latin America," for a discussion of this decision and its implications for the dominant decision-making model in Brazil's health rights litigation. 
In summary, the courts need not be, and often are not, the central arena for the new welfare state politics. At the same time, given that the demands are anchored in constitutional and human rights, the attractiveness of taking a more judicial route hinges in part on the relative likelihood of securing ESR policy goals in the political arena versus the courts. When the former seems more closed and little prone to good governance, the courts are presented with more demands for both policy making and accountability. Conversely, when the courts show themselves to be more inclined to vigorous enforcement of ESR, they are more apt to be called in earlier in the policy process. At times, the judicial intervention remains at the level of improving the process and ensuring that everyone has a voice. At others, it becomes more substantive and directive. The texture of welfare state politics is the result of this complex interplay between courts, social movements, and public officials.

Regardless of the ways in which demands are processed, the social bases of ESR movements include vast numbers of the truly poor. No wonder, then, that the agenda comprises the basic requirements identified in ESR, and a demand for a "basic income." To be sure, job creation, expanding the formal economy, and the base of good waged work - these remain integral to the broader economic demands from the organized left, and unions around the world continue to pursue them. But after two decades of the Washington Consensus, and after its failure to provide the promised employment and prosperity, fewer and fewer progressive forces expect the market to do more than pick up a small portion of the poor. The politics of welfare, in MICs around the world, goes far beyond demands for better industrial policy, to include explicit guarantees of basic goods. Given the prominence of ESR in constitutions and the political imagination, many of these demands are being processed with significant involvement by constitutional courts.

Importantly, many of these demands have been successful. South Africa may have been the pioneer in ESR enforcement, ushered in by the well-known Grootboom case, which recognized a judicially enforceable constitutional right to housing, followed recently by Occupants of Olivia Road, Residents of Joe Slovo Community and Abahlali Basemjondolo Movement. Social assistance rights were the subject of a string of important decisions, including Ngxusa, Khosa/Malaule, Mashava, and Kate. Health rights are also central to the ESR jurisprudence of the South African Constitutional Court, with the already discussed TAC decision, but also in decisions concerning the health rights of inmates (Van Bilion, DuPlooy, and Westville), decisions regarding drug pricing (PMA, Hazel Tau, and Affordable Medicines), and decisions easing restrictions on state purchasing of medications (Interim Procurement). ${ }^{50}$

50 See, generally, the discussions in Jonathan Berger, "Litigating for Social Justice in Post-Apartheid South Africa: A Focus on Health and Education," in Gauri and Brinks, Courting Social Justice, 38-99; and S. Liebenberg, Socio-Economic Rights: Adjudication under a Transformative Constitution (Juta Academic, 2010). 
While South Africa is one of the best-known cases, Latin America has a very substantial experience with ESR demands. Health rights have appeared as central to the more judicialized demands of the new welfare state politics. This issue marks the jurisprudence of Costa Rica's constitutional chamber, ${ }^{51}$ Argentina's Supreme Court, ${ }^{52}$ the Brazilian constitutional court, ${ }^{53}$ and Colombia's Constitutional Court and lower courts. ${ }^{54}$ But the agenda encompasses many other rights as well. The right to water and other environmental rights have been litigated in different contexts, with varying degrees of success. The right has been litigated in contexts marked by deprivation the antidisconnection movement is all about providing water for those who cannot afford it. It has been deployed by marginalized populations affected by industrial pollutants (as in the Mendoza/Riachuelo case, in Argentina) and by indigenous groups seeking to protect a cultural heritage and a way of life (unsuccessfully in Chile, ${ }^{55}$ more successfully in Nicaragua ${ }^{5}$ ). ESR have firmly entered the political realm and transformed the actors involved, the discourse, and the locus of political conflict around distributive issues in Latin America. There have been some successes, although there is much still to do to establish robust and comprehensive welfare states.

There has been criticism of this approach as tending to benefit the better off, at the expense of the poor. Octavio Ferraz, for example, argues forcefully that bringing the courts into the center of the debate is simply a recipe for solidifying the advantages of the already advantaged urban middle class. ${ }^{57}$ Our sense is that these concerns are overdrawn. We have argued elsewhere that these critiques focus on a misleadingly narrow slice of health rights litigation, and that, if one were to broaden the view, the conclusion might be quite different..$^{8}$ Moreover, there is empirical evidence emerging that the poor do not fare too badly, even when we limit the focus to judicial outcomes as opposed to broader policy and political strategies and results. ${ }^{59}$ And in

${ }^{51}$ Bruce M. Wilson, et al., "Legal Opportunity Structures and Social Movements: The Effects of Institutional Change on Costa Rican Politics," Comparative Political Studies 39 (2006): 325; Bruce M. Wilson, "Rights Revolutions in Unlikely Places: Colombia and Costa Rica," Journal of Politics in Latin America 1 (2009): 59.

52 Paola Bergallo, "Courts and Social Change: Lessons from the Struggle to Universalize Access to HIV/ AIDS Treatment in Argentina," Texas Law Review 89 (2011): 1611.

53 Hoffman and Bentes, "Accountability for Social and Economic Rights in Brazil."

54 Yamin, et al., "Colombia - Judicial Protection of the Right to Health," in Yamin and Gloppen, Litigating Health Rights; Wilson, "Rights Revolutions," supra n. 52.

55 Anne Skjaevestad, "The Mapuche People's Battle for Indigenous Land: Litigation as a Strategy to Defend Indigenous Land Rights," in Cultures of Legality: Judicialization and Political Activism in Latin America, ed. Javier Couso, et al. (Cambridge University Press, 2010).

${ }_{56}$ For a discussion of this, see Awas Tingni Community v. Nicaragua, Rep. Inter-Am. Ct. H.R. (ser. C) No. 79 (2001), a decision by the Interamerican Court of Human Rights.

57 Ferraz, "Harming the Poor through Social Rights Litigation." See also, V.A. Da Silva and F. V. Terrazas, "Claiming the Right to Health in Brazilian Courts: The Exclusion of the Already Excluded?," Law \& Social Inquiry 36 (2011): 825-53.

$5^{8}$ Brinks and Forbath, "Social and Economic Rights in Latin America."

59 Daniel M. Brinks and Varun Gauri, "The Law's Majestic Equality? The Distributive Impact of Litigating Social and Economic Rights," World Bank Policy Research Working Paper No. 5999 (2012), available at http://ssrn.com/abstract $=2024823$. 
all these cases, it is clear that the demands arise because the state has, at least so far, not addressed the perceived need.

Whether the broad legal and constitutional turn in welfare politics and movement strategies is wise policy or economic brinksmanship; whether it embodies nothing more than a palliative and a veil for the harsher side of neoliberal political economy; or whether instead it is a new and promising kind of social democracy that marries the market- and efficiency-minded insights of technocrats and policy makers to the egalitarian commitments of ESR advocates - these questions remain open. But we, at least, are encouraged. Many of the approaches to a new developmental state emphasize exactly the kind of issues that are at the core of the ESR movements across the world, in particular, health care and education. Investments in these issues, they argue, will strengthen the economic position of states struggling to compete in a globalized economy at the same time that they offer a floor of economic and social inclusion that supports human dignity and broad political participation.

\section{CONCLUSION}

In short, the language of ESR has been deployed in many MICs to prompt a new politics of the welfare state in a postneoliberal moment. The phenomenon seems to have its global center of gravity in the MICs, perhaps because they are caught between the imperative of development in a globalized economy and the tantalizing promise of prosperity in countries that already command a certain amount of resources. This language has channeled demands for many of the basic goods that are central to the old welfare states of high-income countries (HICs) in Western Europe, and has pushed some of the MICs to broaden and deepen their own welfare states. The strategies of social groups seeking to expand the range of, and access to, state services include both traditional lobbying and mobilization, and newer litigation-based efforts. These strategies are usually deployed sequentially or together, in a multipronged effort to change both legislation and practice. The strategies are not always successful, nor are the judicial responses always enlightened. But in many MICs, the politics of the welfare state are marked by signature victories achieved by these groups. The TAC case in South Africa is a global standard bearer for access to modern, state-of-the-art medication, in the face of obstinate refusals by elected officials and appointed bureaucrats. The T-76o health care reform case in Colombia is a dramatic example of how a judicial strategy can eventually engage the entire policy-making community in a joint effort to recraft the national health care system in a country.

These efforts are characteristic of MICs, to a much greater extent than either the HICs or the low-income countries (LICs) in the world. The LICs simply do not have the infrastructure to support robust ESR demands. The HICs, for their part, have neither whole-heartedly embraced the constitutional language of ESR nor 
encouraged judicial interventions to the same degree. We can speculate that this is because courts in MICs are standing in for other policy-making and -monitoring structures that are stronger in the HICs, but this observation deserves additional research. None of this has eradicated poverty and need. But there is considerable evidence emerging that it can make a difference, and that, done well, it can benefit those who have been left behind by existing MIC welfare states. 